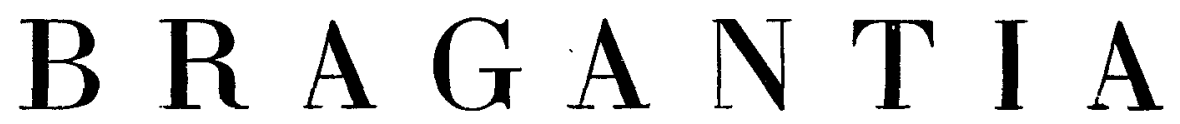

Boletim Científico do Instituto Agronômico do Estado de S. Paulo

Vol. 28

Campinas, janeiro de 1969

N. ${ }^{\circ} 1$

\title{
MORFOLOGIA DAS PARTÍCULAS DO VÍRUS DO ANEL DO PIMENTÃO ( $\left.{ }^{1}\right)$
}

E. W. Kitajima, A. R. Oliveira e A. S. Costa, engenheiros-agrônomos, Seção de Virologia, Instituto Agronômico

\section{SINOPSE}

Partículas tubulares, ca. $25 \mathrm{~m}_{\mu}$ em diâmetro externo e com um canal axial de $4 \mathrm{~m}_{\mu}$ de largura, foram observadas em preparações rápidas ou purificadas e no interior de tecidos de plantas infetadas pelo virus do anel do pimentão (VAP). Dois tipos de partículas, quanto ao comprimento normal. respectivamente 55 e $200 \mathrm{~m}_{\mu}$, foram notadas em preparações in vitro, e com infetividade associada sòmente às partículas longas.

Partículas, de preparações purificadas, quando incubadas com ribonuclease ou tripsina, não se alteravam, embora em algumas das experiências a tripsinização houvesse induzido uma agregação terminal das partículas. Quando aquecidas a temperaturas superiores a $65-70^{\circ} \mathrm{C} / 10^{\prime}$, há, paralelamente à redução da infetividade, uma decomposição dos virions, que se transformam em material pulverulento.

Em secções ultra-finas de tecidos infetados foram encontrados agregados ordenados de partículas similares àquelas encontradas in vitro, no citoplasma. Essas inclusões constituiam-se somente de partículas longas (ca. $200 \mathrm{~m} \mu$ ), e a ausência de grupos de partículas curtas características sugere que estas representem fragmentos aproximadamente iguais a 1/4 das longas.

\section{1 - INTRODUÇÃO}

Uma moléstia de vírus afetando o pimentão foi recentemente encontrada no município de São Carlos, S.P. O vírus causador foi denominado vírus do anel do pimentão (VAP). Posteriormente outros isolados dêste vírus foram encontrados em dife-

(1) Parte da tese para doutoramento apresentada pelo autor principal. Parcialmente subvencionada pela Fundacão de Amparo a Pesquisa do Estado de Sáo Paulo (C. Agron. 66/107) e pelo Conselho Nacional de Pesquisas (TC 4827). Recebida para publicacáo em 7 de outubro de 1967. 
rentes localidades. As características biológicas e determinações preliminares da morfologia e relações serológicas do VAP mostraram ser êle integrante do grupo do vírus do "rattle" do fumo (8).

No presente trabalho descrevem-se detalhes da morfologia das partículas do VAP, observados em preparações rápidas ou purificadas e no interior das células infetadas, bem como o efeito de certos tratamentos físicos e químicos sôbre a estrutura das partículas.

\section{2 - MATERIAL E MÉTODOS}

Virus - Quatro isolados do VAP - São Carlos, Bidens, Itapeva e Jacutinga (8) - mantidos na coleção da Seção de Virologia, Instituto Agronômico, foram utilizados no presente estudo.

Plantas hospedeiras - As seguintes plantas, sadias ou infetadas com um dos isolados do VAP acima mencionados, foram empregadas nesta investigação: Solanaceae - fumo (Nicotiana tabacum L.)-s $\left(^{2}\right) ; N$. glutinosa L.-S; maria-pretinha (Solanum nigrum L.)-s; pimenta (Capsicum pendulum Wild.)-s; pimentāo (Capsicum annuum L.)-s; tomateiro (Lycopersicon esculentum Mill.)-s; Physalis sp.-s; Chenopodiaceae - Chenopodium amaranticolor Coste \& Reyn.-11; C. quinoa Wild.-11; C. murale L.-11; Labiatae - cordão-de-frade (Leonotis nepaetifotia L.)-s ; Amaranthaceae - perpétua (Gomphrena globosa L.)-s; Compositae - girassol (Helianthus annuus L.); emília (Emília flammea L. )-s; picão (Bidens pilosa L.)-s. Estas plantas-teste foram mantidas em estufa, após terem sido inoculadas mecânicamente com um dos quatro isolados do VAP, e utilizadas para microscopia electrônica, quando mostravam sintomas conspícuos da infecção.

Preparações rápidas para microscopia electrônica - Amostras de fôlhas de plantas, infetadas ou sadias, foram preparadas para microscopia electrônica pela técnica do "leaf-dip" convencional (1) ou combinada com a da contrastação negativa (21). As partículas observadas ao microscópio electrônico $\left(^{3}\right)$ foram fotografadas a 5.000 ou $20.000 x$ e medidas a uma magnificação final de $50.000 x$. O comprimento das partículas foi distribuído em classes de $25 \mathrm{~m} \mu$

$\left(^{2}\right)$ s - infecção sistêmica; 11 - lesões locais.

$\left({ }^{3}\right)$ Doação conjunta da Fundação Rockefeller e do Conselho Nacional de Pesquisas. 
de intervalo. Em alguns casos, mediçóes comparativas das partículas do VAP e do vírus do mosaico comum do fumo (VMCF) foram efetuadas para o contrôle dos resultados.

Contrastação negativa e positiva de preparações purificadas - Preparações purificadas do VAP, obtidas a partir de suco de plantas de fumo, sistêmicamente infetadas pelo isolado são Carlos, através de ciclos de ultracentrifugação diferencial e em gradiente de densidade (30), foram utilizadas para investigar a ultraestrutura de suas partículas após serem contrastadas negativa (4) ou positivamente (19), respectivamente com solução de ácido fosfotúngstico a $1 \%$ e solução saturada de acetato de uranila.

Tratamento enzimático do VAP - A fim de avaliar o efeito da tripsina e/ou ribonuclease sôbre as partículas do VAP, preparações purificadas, antes ou depois da ultracentrifugação em gradiente de densidade, foram incubadas em presença destas enzimas, a concentração final de $1 \%$, em banho-maria a $37^{\circ} \mathrm{C}$, durante uma hora. Findo o tratamento, amostras do material incubado e do contrôle (aquecido ou não) foram examinadas ao microscópio electrônico, antes e depois de serem ultracentrifugadas para eliminar as enzimas. Amostras do material ultracentrifugado foram testadas quanto à sua infetividade.

Tratamento térmico do VAP - O efeito do tratamento térmico sôbre a estrutura das partículas do VAP foi verificado, examinando-se preparações purificadas e infetivas do VAP, antes e depois de serem aquecidas. Alíquotas do sobrenadante de preparações aquecidas à temperatura constante, durante $10 \mathrm{mi}$ nutos, de $40^{\circ} \mathrm{C}$ a $90^{\circ} \mathrm{C}$, a intervalos de $5^{\circ} \mathrm{C}$ e centrifugadas a $5.000 \mathrm{rpm} / 10^{\prime}$, foram contrastadas negativamente e examinadas ao microscópio electrônico, enquanto outra porção era testada quanto à sua infetividade.

Secções de particulas presentes em preparações purificadas $e$ infetivas, sedimentadas por ultracentrifugação - Partículas presentes em preparações purificadas e infetivas do VAP foram sedimentadas ( $130.000 \mathrm{~g} / 60$ ') e fixadas em ácido ósmico $\left(\mathrm{OsO}_{4}\right)$ a 1\%, em tampão fosfato de sódio $0,2 \mathrm{M}, \mathrm{pH} 7$, durante 12-18 horas (28). A seguir foram desidratadas em série de concentração crescente de acetona e incluídas em Epon 812 (26). Os blocos obtidos foram seccionados em um ultramicrótomo Porter-Blum, modêlo MT-1, utilizando-se navalhas de vidro. As secções foram contrastadas com citrato (32) ou hidróxido (20) de chumbo e acetato de uranila (37). 
Secções de tecidos de plantas infetadas pelo VAP - Pequenos fragmentos de tecido foliar (tomateiro, picão, fumo, Nicotiana gutinosa, pimenta, pimentão, perpétua, Chenopodium amaranticolor e maria-pretinha), tecido radicular (tomateiro, fumo), tecidos da flor e do fruto (tomateiro) de plantas infetadas com um dos isolados do VAP foram fixados e processados para histologia electrono-microscópica, como acima descrito para as partículas de preparações purificadas sedimentadas.

\section{3 - RESULTADOS}

Em tôdas as preparações rápidas ("leaf dip" convencional ou combinado com contrastação negativa) obtidas de plantas infetadas pelo VAP, partículas em forma de bastonetes rígidos, de 20-25 $\mathrm{m} \mu$ de diâmetro, foram consistentemente encontradas (estampas $1,2 A, 2 B$ ). Em nenhum caso foram elas detectadas em plantas contrôles, não inoculadas. Estas partículas eram de dois tipos predominantes quanto ao comprimento, e a curva de distribuição dêste formava dois picos conspícuos nas classes de 50 e $200 \mathrm{~m} \mu$ (figura 1). O comprimento normal (CN) destas partículas foi calculado baseado nesta curva de distribuição (2), obtendo-se os valores de 54 e 199 mu para o total das partículas medidas ( cêrca de 8 mil) (quadro 1). Também não se notou diferenças nos valores do $\mathrm{CN}$ das partículas curtas ou longas do VAP, quando o material infetado foi preparado para microscopia electrônica pelo método do "dipping" convencional (1) ou combinado com a contrastação negativa (21) (figura $2 A$ e quadro $2 A$ ).

Determinação do CN das partículas do VAP e do VMCF, em condições comparativas, deu sistemàticamente valores ao redor de $300 \mathrm{~m} \mu$ para o VMCF e 55 e $200 \mathrm{~m} \mu$, respectivamente, para as particulas curtas e longas do VAP (figura $2 B$ e quadro $2 B$ ).

A proporção entre partículas longas e curtas, nas preparações rápidas, variava de um valor pouco inferior à unidade, até cêrca de 20 longas para 1 curta, tendo sido em média 2,5 (quadro 1 ). Deve-se contudo mencionar que para obtenção das micrografias electrônicas, para economia de tempo e material, selecionavam-se áreas em que a concentração das partículas longas era maior que a usual ( ca. 20 ou mais partículas longas por fotografia, a uma magnificação de 5.000x).

Em algumas preparações rápidas, observaram-se grupos de partículas longas, dispostas mais ou menos ordenadamente ao redor de remanescentes de uma estrutura celular, provàvelmente mitocôndrios (estampa 1-A, $C, E$ ). 


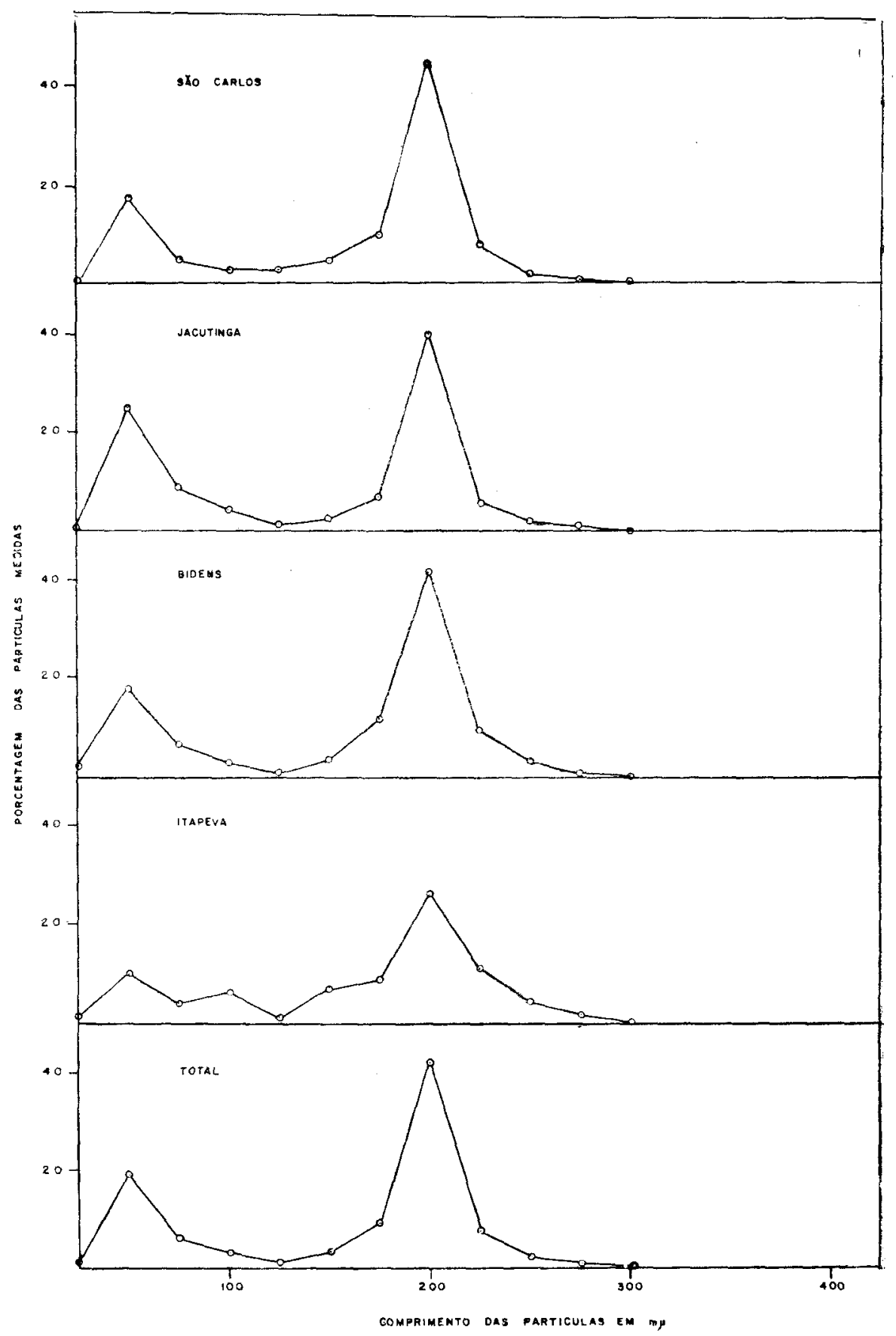

Figura 1. - Curva de distribuição dos comprimentos das partículas de diferentes isolados do VAP. Preparaçốes feitas pelo método do "dipping" convencional ou combinadas com contrastação negativa. 
QUADRO 1. - Resultado geral das determinações dos comprimentos normais plantas

\begin{tabular}{|c|c|c|c|c|c|c|c|c|c|c|}
\hline \multirow{3}{*}{$\begin{array}{c}\text { Planta } \\
\text { hospedeira }\end{array}$} & \multicolumn{10}{|c|}{ Isolado } \\
\hline & \multicolumn{5}{|c|}{ São Carlos } & \multicolumn{5}{|c|}{ Jacutinga } \\
\hline & $n_{1}\left({ }^{1}\right)$ & $\mathrm{CN}_{1}$ & $\mathrm{n}_{2}$ & $\mathrm{CN}_{2}$ & $\mathbf{N}$ & $\mathrm{n}_{1}$ & $\mathrm{CN}_{1}$ & $\mathrm{n}_{2}$ & $\mathrm{CN}_{2}$ & $\mathbf{N}$ \\
\hline Fumo $\ldots \ldots \ldots \ldots \ldots \ldots$ & 346 & 53 & 565 & 199 & 1105 & 66 & 59 & 157 & 201 & 275 \\
\hline N. glutinosa $\ldots \ldots \ldots \ldots \ldots$ & 74 & 55 & 167 & 200 & 279 & 153 & 58 & 174 & 201 & 374 \\
\hline Physalis sp $\ldots \ldots \ldots \ldots \ldots$ & 24 & 55 & 56 & 198 & 104 & --- & -- & --- & --- & $-\cdots$ \\
\hline Tomateiro $\ldots \ldots \ldots \ldots \ldots$ & 21 & 56 & 160 & 200 & 193 & 42 & 57 & 114 & 204 & 227 \\
\hline Maria-pretinha $\ldots \ldots \ldots \ldots$ & -- & - & $\cdots-$ & -- & --- & -- & -- & -- & --- & $-\cdots$ \\
\hline Pimentão $\ldots \ldots \ldots \ldots \ldots$ & 16 & 55 & 77 & 204 & 106 & 31 & 56 & 159 & 202 & 220 \\
\hline Fimenta $\quad \ldots \ldots \ldots \ldots \ldots \ldots$ & 98 & 53 & 309 & 199 & 469 & 60 & 55 & 173 & 197 & 251 \\
\hline Emilia $\ldots \ldots \ldots \ldots \ldots \ldots$ & 5 & 50 & 125 & 198 & 169 & --- & -- & --- & --- & --- \\
\hline Girassol $\ldots \ldots \ldots \ldots \ldots \ldots$ & 45 & 54 & 72 & 197 & 129 & --- & -- & --- & -- & -- \\
\hline Picão $\ldots \ldots \ldots \ldots \ldots \ldots$ & -- & - & --- & $-\cdots$ & $\cdots-$ & $=-$ & -- & -- & -- & --- \\
\hline C. amaranticolor $\ldots \ldots \ldots$ & 52 & 54 & 161 & 199 & 235 & 74 & 54 & 124 & 199 & 221 \\
\hline c quinoa $\ldots \ldots \ldots \ldots \ldots$ & 51 & 58 & 163 & 200 & 254 & 284 & 52 & 180 & 196 & 502 \\
\hline C. murale $\ldots \ldots \ldots \ldots \ldots$ & 29 & 52 & 120 & 196 & 175 & $\ldots$ & -- & --- & -- & -- \\
\hline Perpétua $\ldots \ldots \ldots \ldots \ldots \ldots$ & 37 & 55 & 194 & 200 & 274 & 95 & 57 & 130 & 197 & 279 \\
\hline Cordāo-de-frade & 11 & 50 & 75 & 200 & 91 & --- & -- & $=-$ & -- & $=-$ \\
\hline TOTAL $\ldots \ldots \ldots \ldots$ & 809 & 54 & 2244 & 199 & 3583 & 805 & 55 & 1211 & 199 & 2349 \\
\hline
\end{tabular}

$\left.{ }^{1}\right) n_{1}$ - número de partículas nas classes de 25 a $75 \mathrm{m \mu}$, inclusives; $\mathrm{n}_{2}$ - idem, respectivamente, comprimento normal das particulas curtas e longas, em $\mathrm{mp}$. 
de quatro isolados do vírus do anel do pimentão que infeta diferentes hospedeiras

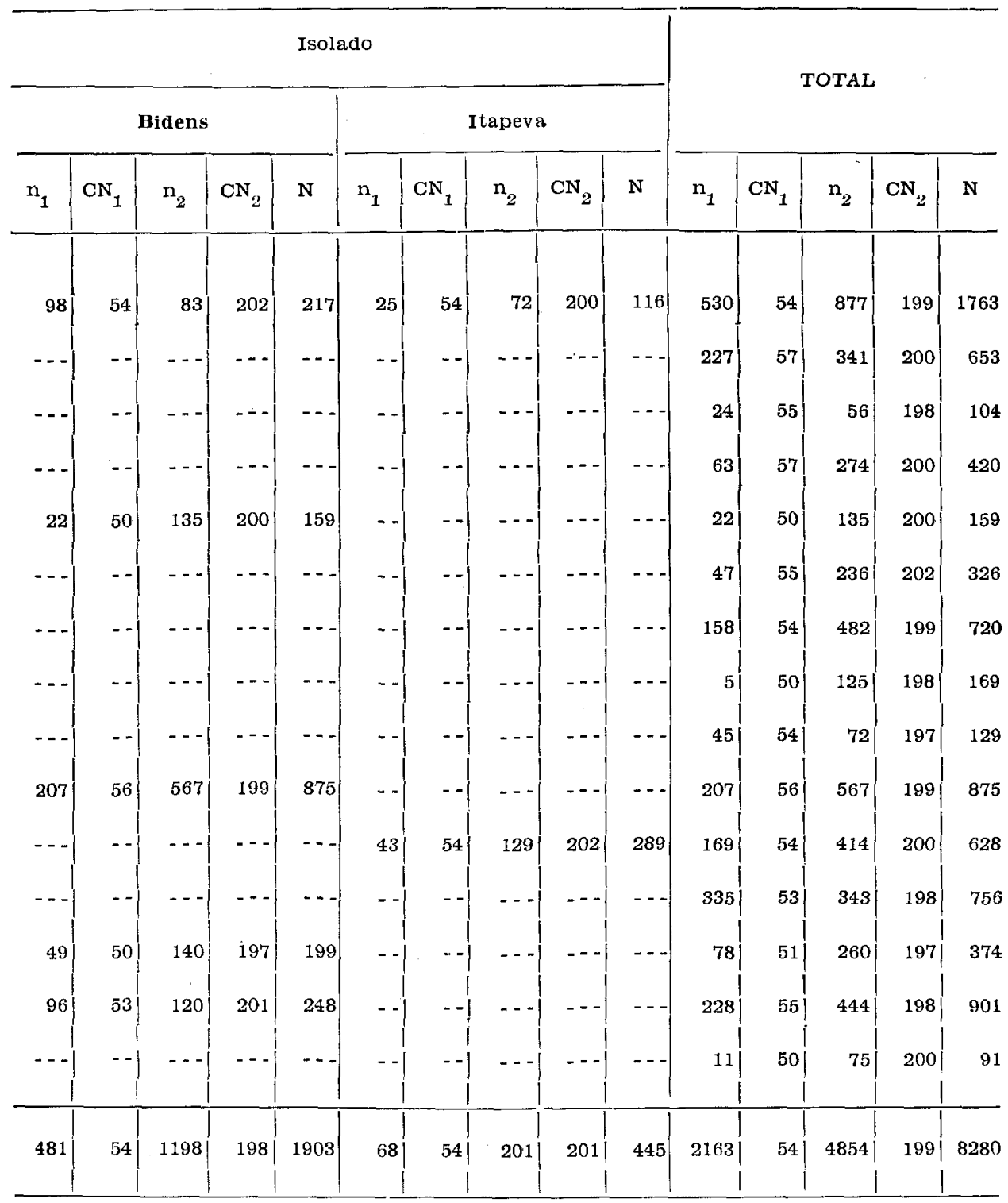

nas classes de 175 a $200 \mathrm{mp} ; \mathrm{N}$ - número total de partículas medidas; $\mathrm{CN}_{1}$ e $\mathrm{CN}_{2}$ - 


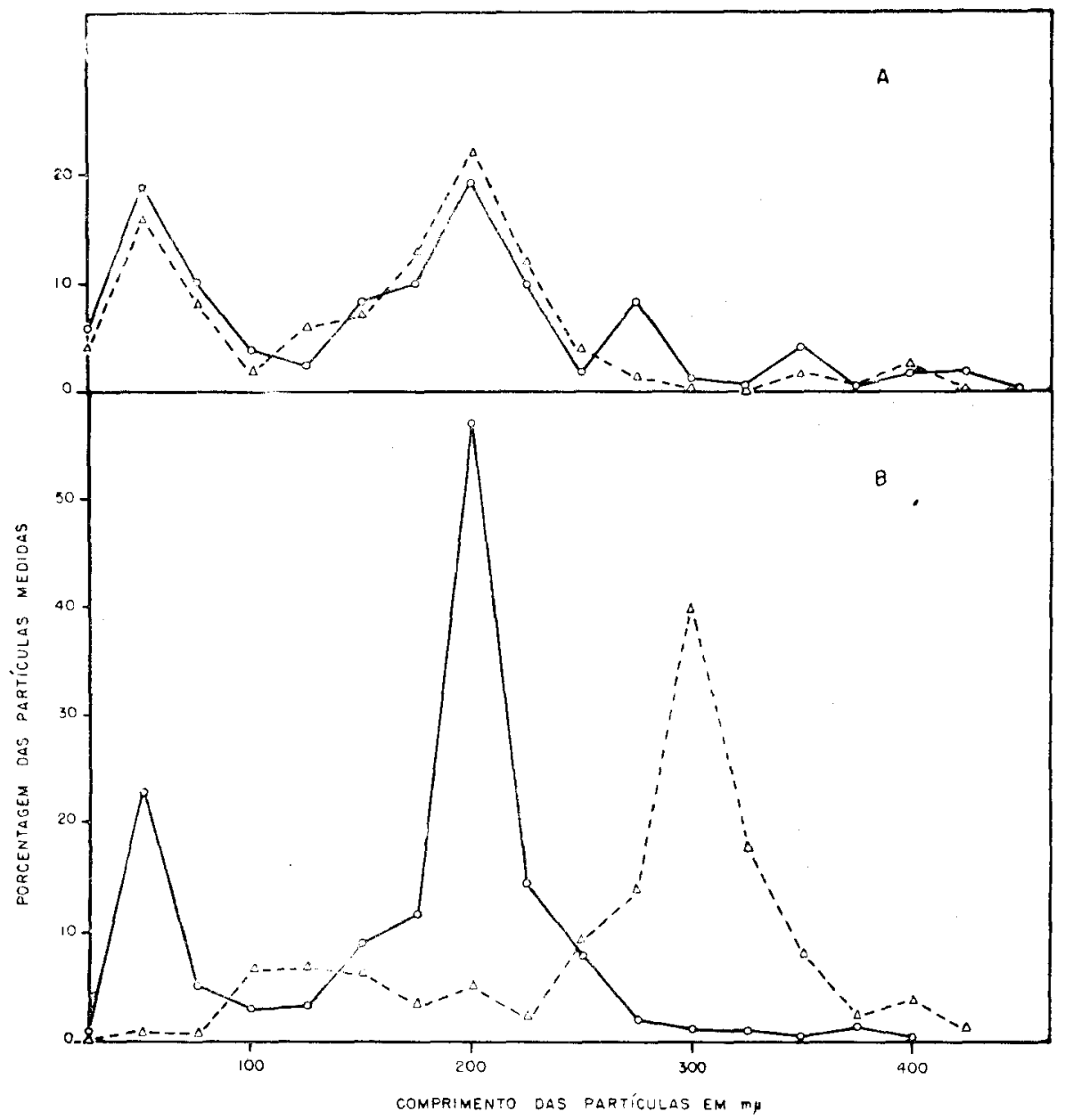

Figura 2. - A- Curva de distribuição dos comprimentos das partículas do isolado São Carlos do VAP, em preparaçóes feitas pelo método do "dipping" convencional (o- -0$)$ ou combinado com contrastação negativa $(\Delta--\Delta)$; B- Idem, das particulas do isolado São Carlos do VAP (o-_-o) e do VMCF ( $\boldsymbol{A}_{--\boldsymbol{A}}$, obtidas de plantas de fumo, e medidas em condiçóes comparativas.

Em preparações purificadas do VAP houve também predominância dos dois tipos de partículas quanto ao comprimento (estampa 6-A). Estas formavam uma curva de distribuição tìpicamente bimodal, não tendo sido, os valores dos CN determinados, diferentes daqueles obtidos em preparações rápidas (figura $3-A$ e quadro 3 ). Nestas preparações houve contudo a prevalência das partículas curtas sôbre as longas (figura $3-A$ ). 
QUAdRo 2. - Comprimento normal das partículas do VAP. A -- Preparações feitas pelo método do "leaf dip" convencional versus "leaf dip"-contrastação negativa; B - Medição comparativa das particulas do VAP (isolado de São Carlos) e do VMCF

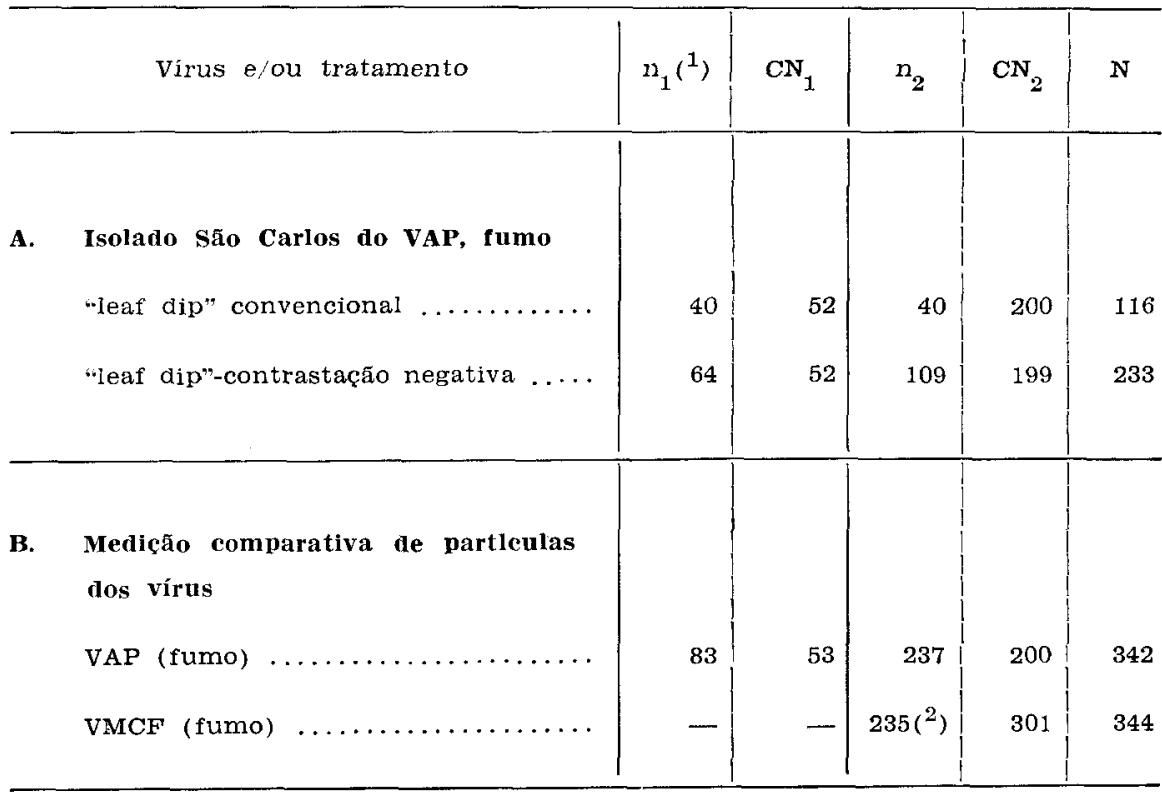

(1) $\mathrm{n}_{1}$ - número de partículas nas classes de 25 a $75 \mathrm{mp}$, inclusives; $\mathrm{n}_{2}$ - idem, nas classes de 175 a $225 \mathrm{mp} ; \mathrm{N}$ - número total de partículas medidas; $\mathrm{CN}_{1}$ e $\mathrm{CN}_{2}$ - respectivamente, comprimento normal das partículas curtas e longas.

( $\left.{ }^{2}\right)$ Número de partículas nas classes de 250 a $350 \mathrm{mp}$, inclusives.

A ultracentrifugação das preparações purificadas do VAP, em gradiente de densidade, produz duas camadas distintas $(29,33)$. Uma, a $25 \mathrm{~mm}$ do menisco, denominada de tôpo, que contém predominantemente partículas curtas (estampas 2-C, 3-B; figura $3-B$; quadro 3 ). A outra, mais abaixo, a $35 \mathrm{~mm}$ do menisco, designada de fundo, constituia-se quase exclusivamente de partículas longas (estampas $2-D, 3-C$; figura $3-C$; quadro 3 ). Usualmente a contaminação da camada de fundo pelas partículas curtas foi maior que a da camada de tôpo, pelas longas (figura $3-B, C$ ). Com um ciclo adicional de ultracentrifugação em gradiente de densidade (30), esta mistura diminuiu consideràvelmente (quadro 3 ; figura $3-B, C$ ). 


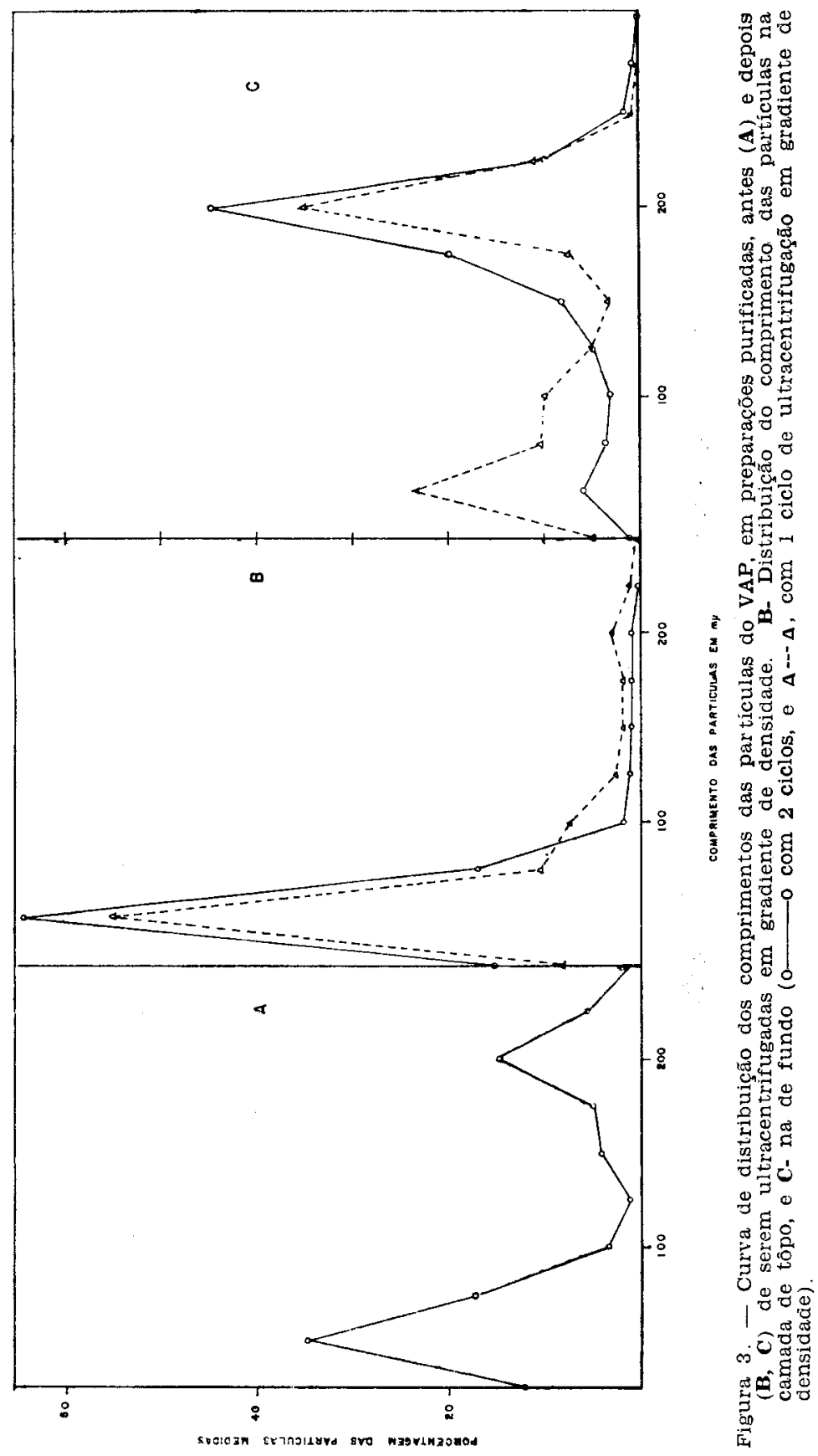


QUADRo 3. - Comprimento normal das partículas do VAP (isolado São Carlos, em fumo), em preparações purificadas, antes e depois de serem ultracentrifugadas em gradiente de densidade

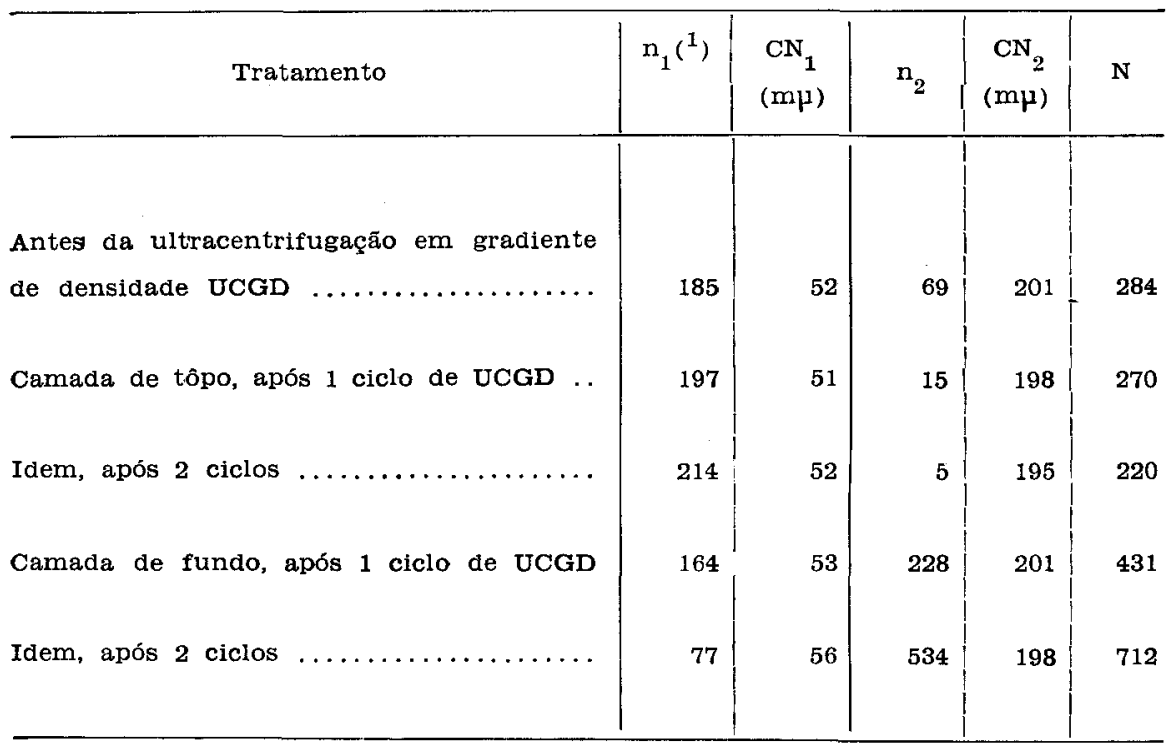

(1) $\mathrm{n}_{1}$ - número de partículas nas classes de 25 a $75 \mathrm{mp}$, inclusives: $\mathrm{n}_{2}$ - idem, nas classes de 175 a $225 \mathrm{mp}$; $\mathrm{N}$ - número total de partículas medidas; $\mathrm{CN}_{1}$ e $\mathrm{CN}_{2}$ - respectivamente, comprimento normal das partículas curtas e longas.

Preparações purificadas e contrastadas negativa ou positivamente, revelaram certos detalhes ultraestruturais das partículas (estampa 3). Do ponto de vista estrutural, não houve diferenças entre as particulas curtas e longas, exceto òbviamente o comprimento. Ambas são tubulares, com diâmetro externo de ca $25 \mathrm{~m} \mu$. O canal axial foi claramente visivel nas preparaçōes contrastadas negativamente, quando fragmentos anelares ficavam de tôpo, e as mensuraçōes mostraram que seu diâmetro era ca. $4 \mathrm{~m} \mu$. Ocasionalmente, a contrastação com acetato de uranila revelava bandas transversais ao longo das partículas, espaçadas de cêrca de 30-40 A (estampa 3-D). As extremidades das partículas não eram iguais, sendo uma delas ligeiramente convexa e a outra côncava; nesta, o canal axial comumente se alargava um pouco.

A incubação de preparações purificadas do VAP, com tripsina e/ou ribonuclease ( RNase) a $37^{\circ} \mathrm{C} / 60^{\prime}$, não afetou sensìvelmente a infetividade dêste vírus e tampouco a estrutura de suas particulas. Mas, em 3 das 5 experiências realizadas, notou-se 0 
efeito da tripsina, traduzido pela agregação terminal, tanto nas preparações que continham partículas curtas como naquelas com partículas longas (estampa $4-A$ a $F$; figura $4-A, B$ ). Testes indicaram que a tripsinização das preparações não infetivas, que continham partículas curtas sòmente, não as tornou capazes de iniciar infecção, mesmo com a agregação terminal e conseqüente aparecimento de partículas de $200 \mathrm{~m} \mu$ ou mais de comprimento.

Os testes de infetividade mostram que a atividade do vírus em preparações aquecidas se mantém até cêrca de $60-65^{\circ} \mathrm{C}$, caindo sensivelmente a $70^{\circ} \mathrm{C} / 10^{\prime}$ e pràticamente desaparecendo a $75^{\circ} \mathrm{C} / 10^{\prime}$ $(8,30)$.

O exame ao microscópio electrônico de amostras de preparações que encerravam sòmente partículas curtas revelou que 0 tratamento a $60^{\circ} \mathrm{C} / 10^{\prime}$ já ocasionava a decomposição das partículas, o que se acentua a $65^{\circ} \mathrm{C} / 10^{\prime}$; a $70^{\circ} \mathrm{C} / 10^{\prime}$ as partículas literalmente desaparecem (estampa 5- $A$ a $C$ ).

Quanto às partículas longas, elas começam a degradar quando aquecidas a $65^{\circ} \mathrm{C} / 10^{\prime}$, acentuando-se esta decomposição até $80^{\circ} \mathrm{C}$. A temperaturas superiores, as partículas decompõem-se totalmente (estampa 5-D a $H$ ).

A degradação térmica das partículas caracterizou-se pela sua transformação em um material pulverulento, constituído de grânulos de 30-40 ${ }_{A}^{0}$ de diâmetro. No início da decomposição, apareceram numerosas partículas semidegradadas, aglutinadas pelo material decomposto, formando massas que lembravam precipitados serológicos. A proporção das partículas, mantendo a integridade estrutural, nessas massas diminuia à medida que a temperatura aumentava. Também foi observada freqüentemente uma intensa fragmentação das partículas em pedaços mais curtos e mesmo anelares. Esta fragmentação foi usualmente conspícua nas preparações que continham partículas longas e na faixa de $70-75^{\circ} \mathrm{C} / 10^{\prime}$, e nas que encerravam as curtas, a $65^{\circ} \mathrm{C}$. Por outro lado, em muitos casos puderam ser notadas partículas parcialmente degradadas, mas mantendo ainda a forma original, bem como uma certa intumescência em outras, resultantes do tratamento térmico (estampa 6- $A$ a $C$ ).

Numa experiência, em que as partículas se achavam suspensas em água destilada, após o tratamento térmico $\left(75-80^{\circ} \mathrm{C} / 10^{\prime}\right)$, o material decomposto não se dispersou, formando pequenas massas esferoidais (estampa 5- $I$ ). Isso não sucedeu nas preparações em que o vírus estava suspenso em solução tampão. 


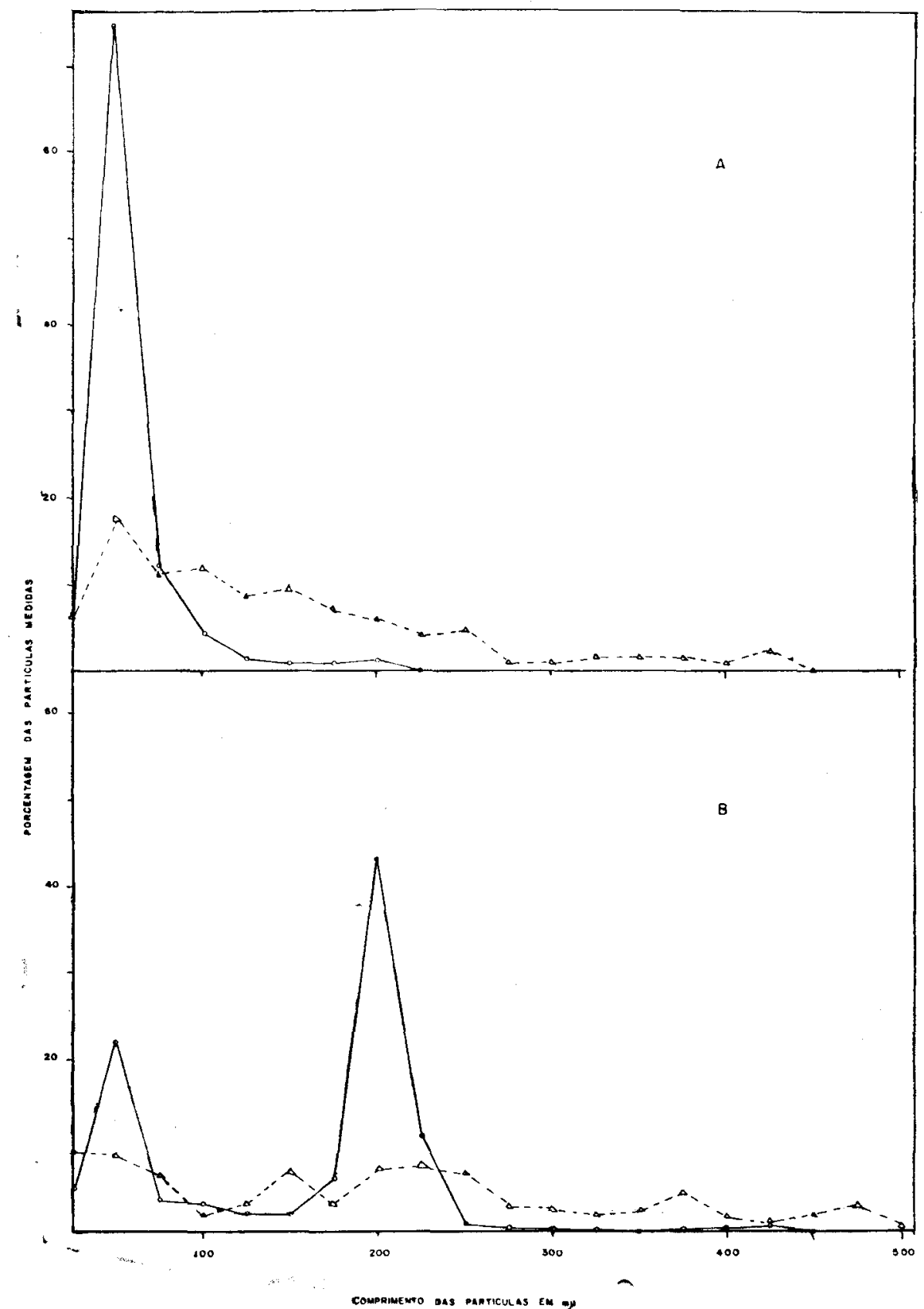

Figura 4. - Curva de distribuição dos comprimentos das partículas da camada de tôpo (A) e do fundo (B), tratadas $(\mathbf{A - A})$ ou náo (0-— tripsina. 
Em secçōes de partículas presentes em preparações purificadas e infetivas, sedimentadas por ultracentrifugação, foram também encontradas sòmente partículas alongadas, orientadas ao acaso (estampa 7-A,B). Seu diâmetro era ligeiramente inferior ao das partículas vistas in vitro. Nas secçōes transversais notava-se claramente o orifício central, e, freqüentemente, um anel

clenso, de $c a .20{ }_{A}^{0}$ de espessura, aparecia margeando êste canal axial (estampa 7-B). O comprimento destas partículas era de difícil determinação. Foram notadas numerosas partículas, bastante longas, indicando ter havido uma agregaçáo terminal. Mesmo assim, ocasionalmente, grupos de partículas de comprimento uniforme, de ca. $200 \mathrm{~m} \mu$, puderam ser encontradas. Apesar da alta rotação necessária para sedimentação, não houve uma compactação muito acentuada das partículas.

Nas secções ultra-finas de tecidos de plantas infetadas pelo VAP foram encontradas sistemàticamente inclusões formadas de partículas alongadas, de aspecto tubular, de morfologia geral idêntica àquelas encontradas nas secções de sedimentos de preparaçóes purificadas e infetivas obtidos por ultracentrifugação (estampa 7-C a $E$ ). Estas partículas formavam inclusóes, nas quais elas se achavam dispostas lado a lado, mais ou menos ordenadamente. Em pràticamente todos os agrupamentos, as partículas tinham cêrca de $200 \mathrm{~m} \mu$ de comprimento. Em nenhum caso foram notados agregados de partículas mais curtas, sendo alguns possiveis casos atribuíveis à secção oblíqua ou tangencial de grupos de partículas longas. Detalhes das investigações histológicas serão relatados em outra publicação.

\section{4 - DISCUSSĀO}

O fato de a infetividade das preparações purificadas do VAP estar consistentemente associada à presença das partículas longas (200 $\mathrm{m} \mu$ ), claramente demonstrada após serem separadas das partículas curtas por ultracentrifugação em gradiente de densidade, constitui evidência de que as partículas longas representam a forma infetiva do VAP. Como evidência complementar pode-se mencionar: a) constante presença das partículas longas em preparações rápidas obtidas de plantas hospedeiras de espécies e familias diferentes, infetadas pelo VAP, mesmo daquelas plantas, das quais o virus ainda não foi purificado, e sua ausência em preparaçōes feitas de plantas sadias; b) A sistemática ocorrência das partículas longas no interior das plantas infetadas. 
O CN das partículas curtas e longas do VAP, respectivamente ca. 55 e $200 \mathrm{~m} \mu$, determinado no presente estudo, confirma as determinações preliminares (8) e estão de acôrdo com as medições feitas por Harrison e Woods (14), com o isolado Bidens do VAP. Não houve variações significativas nos valores obtidos para o CN que pudessem ser atribuídas à diferença do isolado co VAP, da planta hospedeira ou dos métodos de preparo para microscopia electrônica. Isto corrobora as similaridades no comportamento biológico dos diferentes isolados e constitui evidência adicional de que êstes isolados representam estirpes de um mesmo complexo.

Os dados morfológicos do VAP são similares àqueles descritos para os diferentes isolados do vírus do "rattle" do fumo (VRF). Há naturalmente uma certa diferença no comprimento das partículas curtas e longas entre êstes vírus, mas uma determinação precisa sòmente poderia ser feita em condições comparativas. Uma investigação neste sentido já foi feita (14), tendo sido verificadas pequenas diferenças no comprimento das partículas longas, e maiores em relação às curtas, nos diferentes isolados investigados. Além disso, verificou-se que o diâmetro do virus do "early browning" da ervilha (Pisum sativum L.) era ca. $6,5 \%$ menor que o dos demais isolados do VRF.

A comprovação, ao microscópio electrônico, da simetria helicoidal dos vírus alongados, tem sido feita sòmente nos casos em que o nucleocapsídeo helicoidal é menos compacto, como acontece com certos componentes dos myxovírus (17) e do vírus da estomatite vesicular (23, 25), ou com partículas do vírus do amarelo da beterraba (18) e da tristeza do citros (22). Mesmo num caso bastante investigado, como o do VMCF, embora muitos autores afirmassem ter demonstrado sua estrutura helicoidal, já comprovada através de difração de raio-X (16), apenas Finch (10), recentemente, apresentou evidências razoáveis a essa estrutura, ao microscópio electrônico. Deve-se lembrar que há inúmeros artefatos, relacionados ou não à estrutura helicoidal das partículas do virus, que podem produzir imagens ao microscópio electrônico incompatíveis com a configuração deduzida pelo raio-X $\left(2^{7}\right)$.

No caso do VAP e do VRF, os dados obtidos não são suficientes para confirmar a simetria helicoidal dos nucleocapsídeos, apesar de os dados preliminares, obtidos pela difração de raio-X, sugerirem tal estrutura (11). As estrias transversais observadas nas partículas do VRF $(29,31)$ e do VAP não definem perfeita- 
mente se a partícula é formada de subunidades dispostas em hélice ou de pilhas de unidades anelares. Quanto a uma possível configuração helicoidal que as partículas do VAP mostraram quando decompostas tèrmicamente (37), o aspecto produzido é ambiguo, não permitindo tirar conclusões definitivas.

A pequena diferença entre as extremidades das particulas do VAP já fôra apontada para o VRF (14) e para o vírus do mosaico do trigo (3). Acredita-se que ela se deva à forma de banana dos capsômeros, que se disporiam com seu eixo maior ligeiramente inclinado em relação ao eixo maior das partículas (11).

Embora as técnicas de coloração das partículas não trouxessem informações sôbre a localização do ácido nucléico nas partículas do VRF, a secção transversal das partículas nos cortes ultra-finos mostrou uma zona anelar, margeando o canal axial, que se impregna bem com acetato de uranila. Como êste corante tem marcada afinidade para material nucléico (19), parece provável que essa região anelar seja ocupada pelo ácido nucléico do VAP, o que é compativel com o sugerido para o VMCF (16). Offord (31) relata uma zona também anelar, a $80 \stackrel{0}{A}$ do centro das partículas do VRF, mas que, provàvelmente, resulta da sobreposição dos capsômeros.

A pequena diferença nos diâmetros das partículas, determinada em preparações contrastadas negativamente e em secções ultrafinas parece ser atribuivel à ligeira contração dessas partículas durante a fixação. É interessante mencionar que com um isolado californiano do VRF ocorreu um fenômeno inverso (9).

O efeito da tripsina e da RNase sôbre a infetividade e estrutura das particulas do VAP foi quase nulo, confirmando o que fóra anteriormente observado para o VAP (34) e para o VRF (29). Todavia, em alguns casos, a tripsina induziu uma agregaçāo terminal das partículas bastante acentuada. No VMCF isto pode ser provocado pela variação do $\mathrm{pH}$ do meio de suspensão (36), mas no presente caso não há uma explanação satisfatória. Uma sugestão seria de que a tripsina digeriria ligeiramente as extremidades das partículas, tornando-as suscetiveis de se unirem umas com outras pela extremidade. Os testes da inativação térmica das preparaçōes purificadas do VAP concordam com os resultados obtidos anteriormente com suco de planta infetada (8), e o ponto de inativação térmica parece ser ligeiramente inferior ao do VRF (6). 


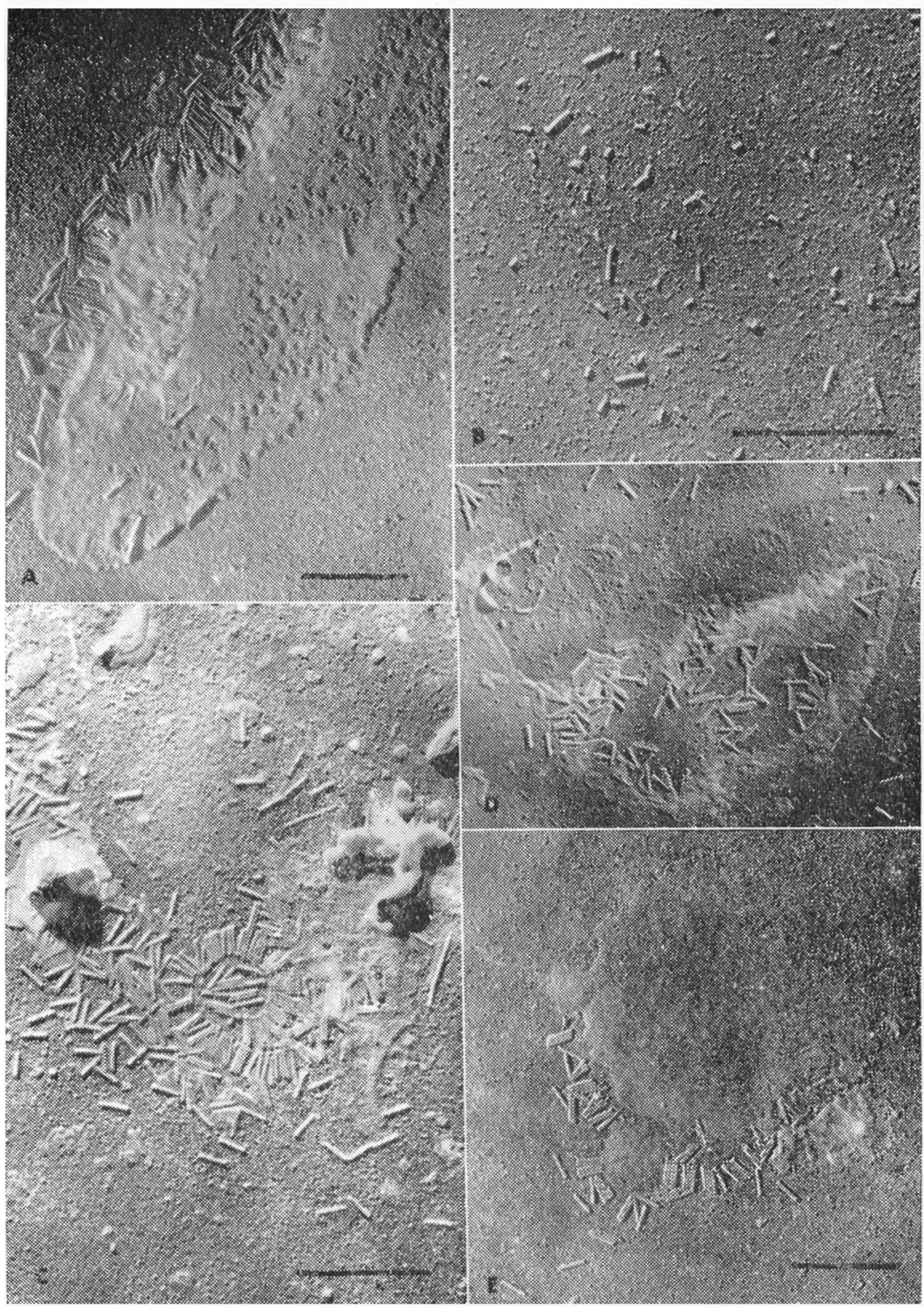

Micrografias electrônicas de preparações feitas pelo método do "dipping", respectivamente das seguintes plantas infetadas pelo VAP: A - Emília; B - Chenopodium quinoa; C - C. murale: D - Nicotiana glutinosa; $\mathbf{E}$ - Picão. Notar nas figuras $\mathbf{A}, \mathbf{C}$ e $\mathbf{E}$ a associação de partículas dispostas regularmente com uma estrutura, possivelmente mitocôndrio. Em B a-gumas partículas ficaram de tôpo, mostrando indícios do canāl axial (seta) Nesta e em outras figuras, quando não assinaladas, as escalas de cada micrografia representa $1 \mathrm{H}$. 


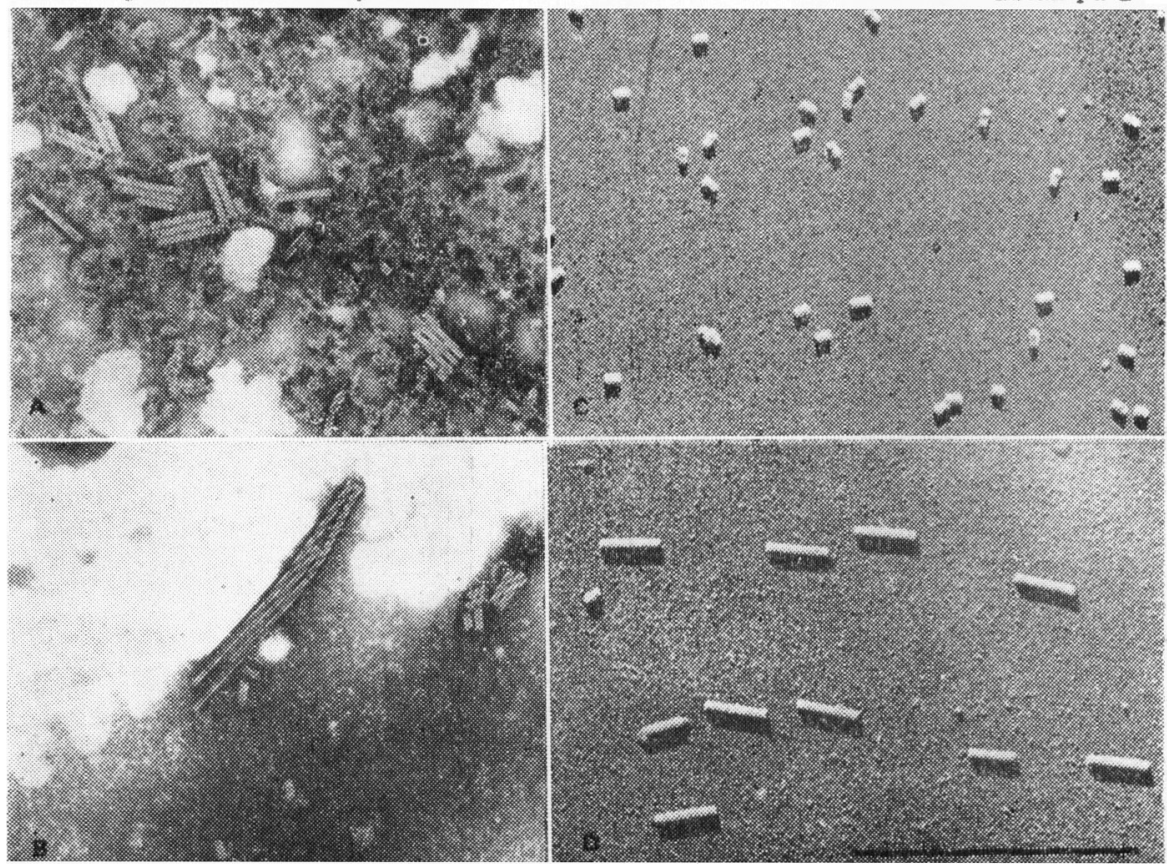

A e B- Preparações feitas pelo método do "dipping", contrastadas negativamente, de pimenteira e fumo, respectivamente. Em $\mathbf{B}$ aparentemente houve uma agregação terminal de partículas curtas; C e D- Preparações purificadas do VAP, em que as partículas curtas (C) foram separadas das longas (D) por ultracentrifugação em gradiente de densidadẹ, 


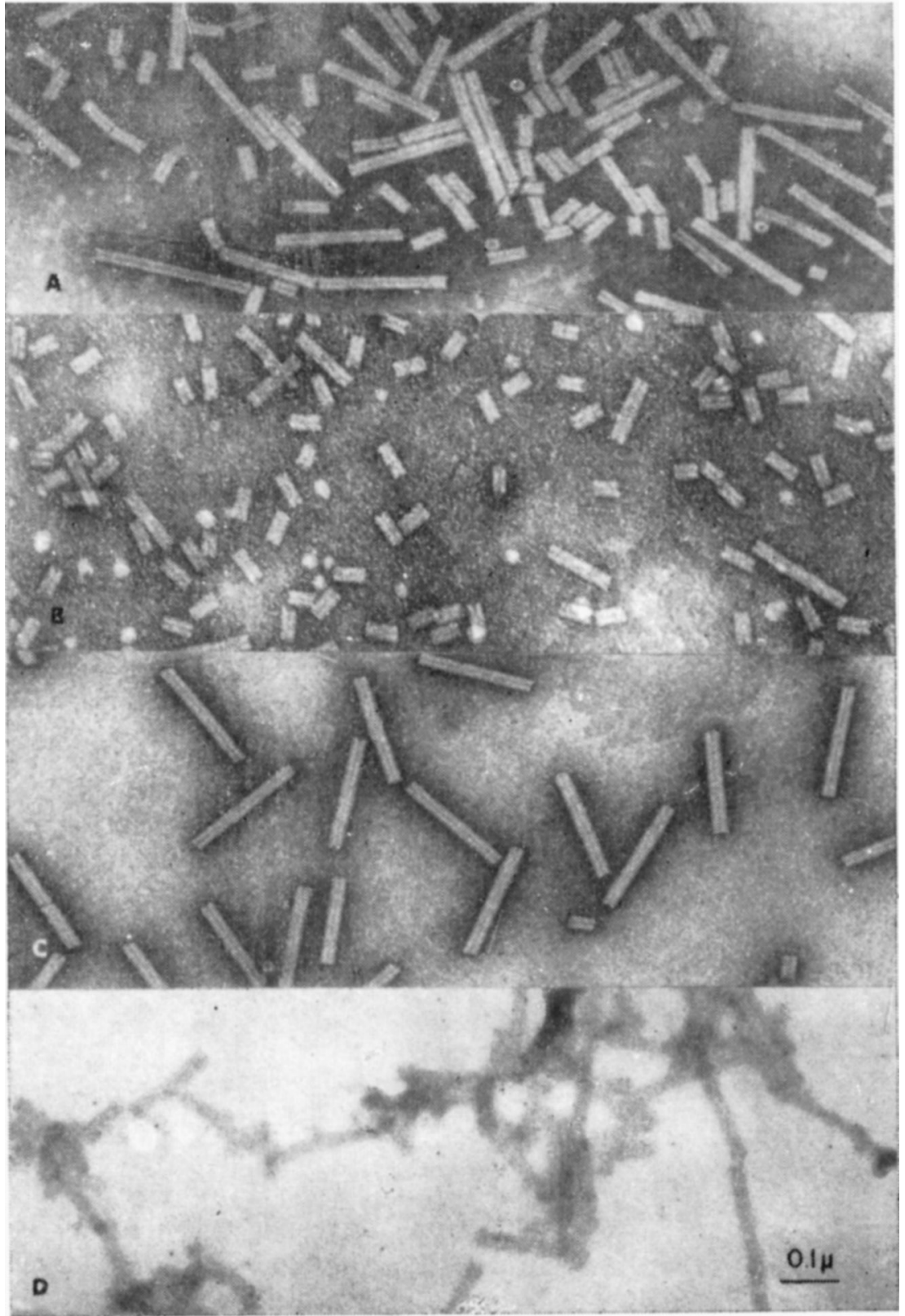

Preparação purificada đo VAP contrastada negativamente antes (A) e depois (B e C) da ultracentrifugaçăo em gradiente de densidade. Em B, amostra da camada de tôpo, constituída predominantemente de partículas curtas, e $\boldsymbol{C}$, da camada de fundo, compostas quase que exclusivamente de partículas longas. D, preparaçấo purificada do VAP contrastada positivamente com acetato de uranila. 


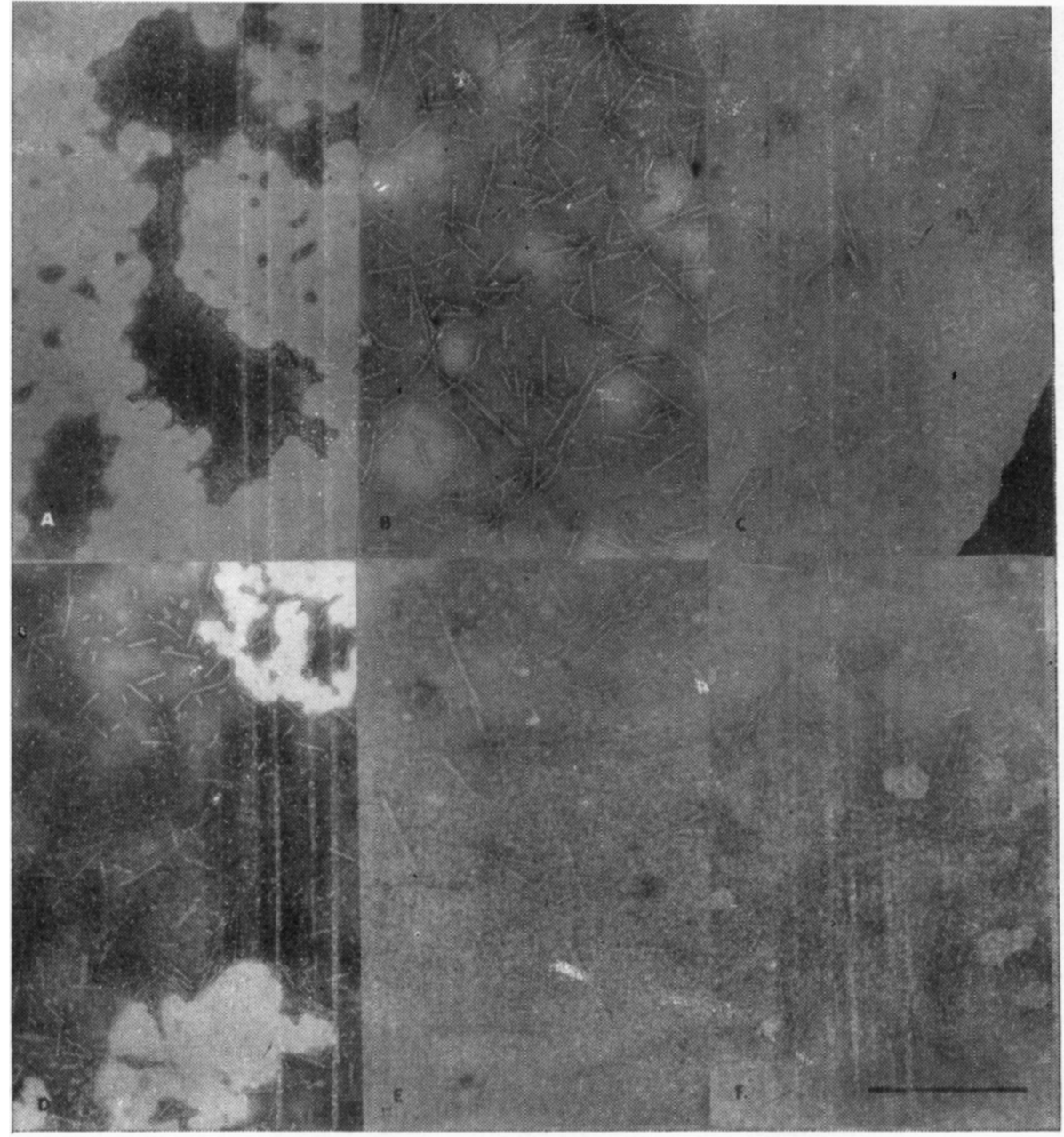

Preparaçōes purificadas contendo partículas curtas (A) ou longas (D), incubadas com tripsina, com (D, F) ou sem (B, E) RNase. Observa-se claramente a ocorrência de uma intensa agregação terminal, tanto das partículas curtas $(\mathbf{B}, \mathbf{C})$ como das longas $(\mathbf{E}, \mathbf{F})$. 


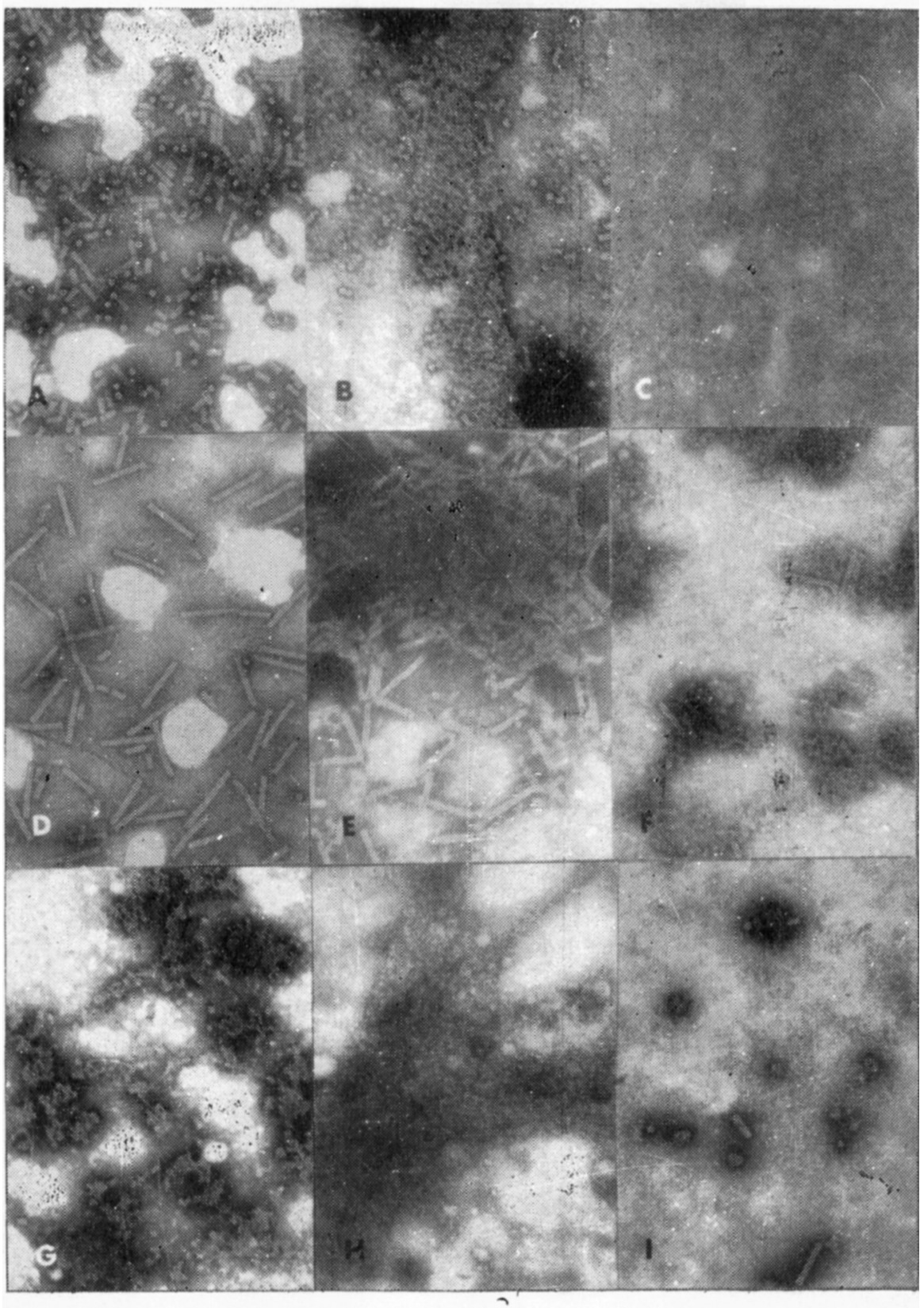

7

Efeito do tratamento térmico sôbre a estrutura das partículas do VAP. A-C- Respectivamente contrôle, tratamento a $65^{\circ} \mathrm{C} / 10^{\prime}$ e $70^{\circ} \mathrm{C} / 10^{\circ}$ da preparação contendo partículas curtas; D-H. Contrôle e tratamentos a $65^{\circ} \mathrm{C} / 10^{\circ}, 7^{\circ} \mathrm{C} / 10^{\prime}, 8^{\circ} \mathbf{C} / 10^{\circ}$ e $90^{\circ} \mathrm{C} / 10^{\circ}$ da preparação contendo partículas longas: I- Tratamento da preparação contendo partículas longas, suspensas em agua destilada, a $80^{\circ} \mathrm{C} / 10^{\circ}$. 


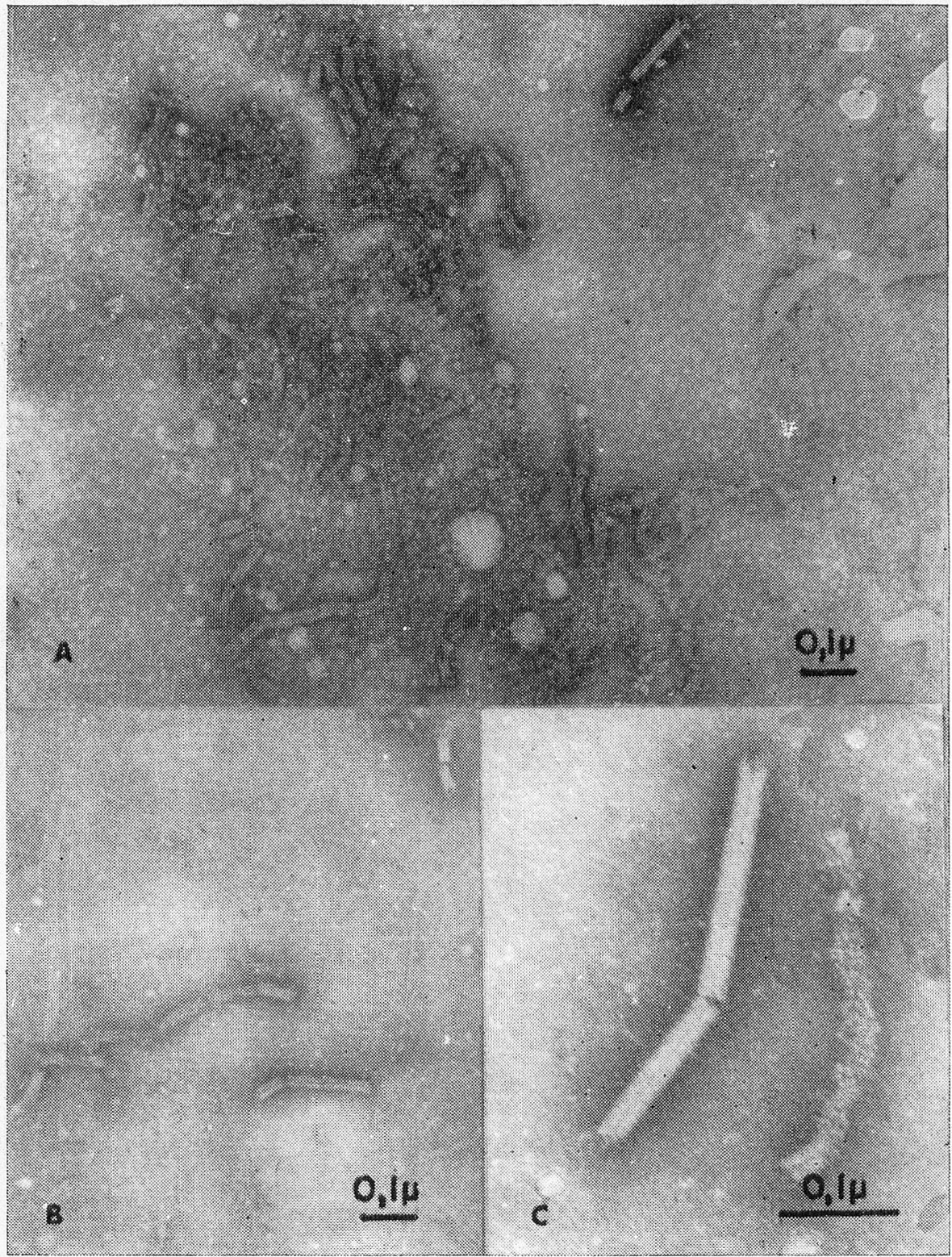

A-C- Detalhes de partículas do VAP, decompostas pela ação do calor (80C/10'). As partículas acham-se total ou parcialmente transformadas em um material pulverulento, finalmente granular de 30-40 A de diâmetro. 


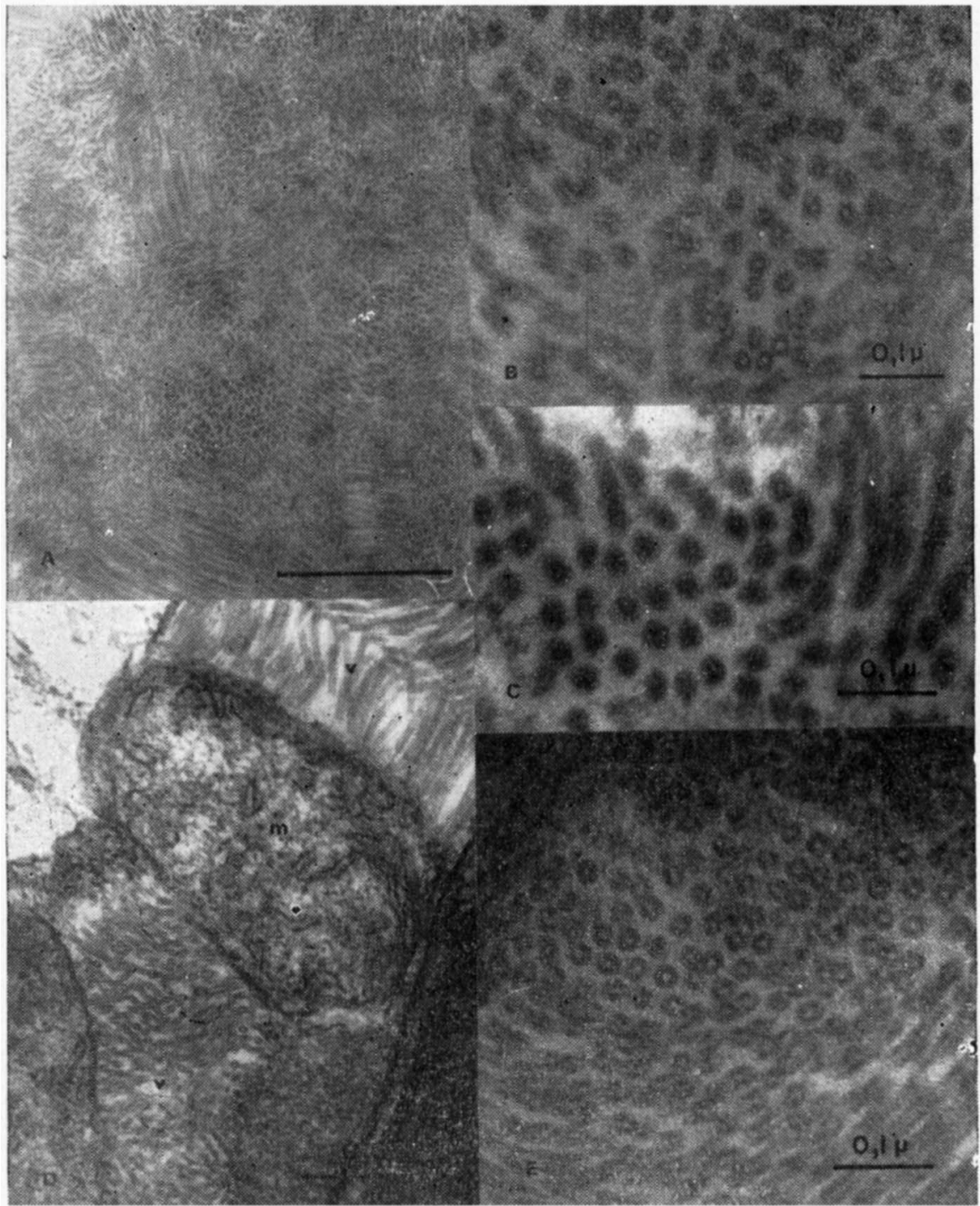

A e B- Secções de sedimentos de preparações purificadas e infetivas do VAP, obtidos por ultracentrifugação; C-E- Inclusốes citoplasmáticas formadas de partículas alongadas em células de picão (C), Chenopodium amaranticolor (D) e Nicotiana glutinosa (E). Notar a semelhança das particulas observadas em A e B, com aquelas presentes nas fotos C-E. As partículas revelam claramente sua natureza tubular. Em algumas micrografias pode-se perceber um anel denso, margeando o canal axial. 
Silva ( 34 ) descreve a ruptura de partículas do VAP em pequeros fragmentos anelares ou desorganização e inchamento ao longo das partículas como conseqüência do aquecimento a temperaturas superiores a $86^{\circ} \mathrm{C} / 90^{\prime \prime}$. No presente trabalho, notou-se que a decomposição vai além, transformando as partículas em massas amorfas, constituídas de grânulos de 30-40 ${ }_{\AA}^{\circ}$ de diâmetro, e que possivelmente representariam um ou mais capsômeros. Embora não seja condição essencial, pois freqüentemente as partículas se transformavam diretamente na massa amorfa, a fragmentação das partículas em pequenos pedaços e anéis usualmente precede esta decomposição e parece representar um estádio intermediário dêste processo. Isto explicaria porque as preparações que contêm sòmente partículas curtas são mais sensiveis ao calor do que as que contêm partículas longas.

O aquecimento das partículas do VAP em presença de água destilada, ao invés da solução tampão fosfato, leva à formação de pequenas massas do material decomposto pelo calor, provàvelmente decorrente da não dispersão dêsse material decomposto. Estas observações confirmam, com certos detalhes adicionais, os estudos feitos sôbre degradação térmica do VMCF, de que a dispersão da porção decomposta das partículas do vírus seria łacilitada pela presença de sais (15).

Além das partículas longas, infetivas, em tôdas as preparações do VAP e de outros vírus do grupo do VRF, acham-se presentes um ou mais tipos de partículas curtas. Sua natureza é ainda controvertida, havendo divergências quanto à sua origem e função. Mas, os trabalhos publicados com diferentes isolados åo VRF têm demonstrado consistentemente que partículas curtas, sòmente, não são capazes de iniciar a infecção, o que também sucede com o VAP. As possíveis alternativas para explicar a natureza das partículas curtas seriam: a) Elas representam fragmentos das partículas longas; b) As partículas curtas seriam formas intermediárias de um processo de sintese das partículas, por crescimento terminal, como sugerida por Commoner ( 7 ), para - VMCF. Uma variante dessa idéia é a de Köhler (24), que sugere pontos de ruptura ao longo das partículas em crescimento, alternadamente, a distâncias equivalentes ao comprimento das partículas curtas e longas; c) As partículas curtas seriam produtos colaterais não infetivos, da infecção pelos vírus do grupo do VRF, e portanto diferente das partículas longas $(9)$; d) As partículas curtas e longas interagem-se simbiòticamente $(12,25)$. 
No presente trabalho, a primeira hipótese é julgada mais provável. Isso se baseia na ausência de inclusões intracelulares formadas de partículas curtas $(55 \mathrm{~m} \mu)$. Partículas de comprimentos variados, menores que $200 \mathrm{~m} \mu$, sòmente aparecem quando agregados de partículas longas se desorganizam, como conseqüência da decadência celular decorrente da infecção, sendo assim bastante forte a sugestão de que elas se originariam da ruptura das partículas longas nesse processo. Por outro lado, a proporção entre partículas longas e curtas do VAP in vitro, baseada em estimativas espectrofotométricas (34) e nas contagens em preparações rápidas, é ao ređor de $3: 1$. Em preparações purificadas essa proporção pode chegar até 1:20 (13). Se as partículas curtas são realmente sintetizadas nas células, seria razoável esperar sua ocorrência intercelular, numa proporção aproximada.

A prevalência marcante de partículas de $c a .55 \mathrm{~m} \mu$ e $200 \mathrm{~m} \mu$ de CN torna difícil aceitar a teoria de que as partículas curtas seriam formas imaturas ou intermediárias de um processo sintético, por crescimento terminal, pois seria de esperar que partículas com diferentes comprimentos ocorressem numa proporção similar. Quanto à sugestão de Köhler (24), se válida, faria com que partículas curtas e longas ocorressem numa freqüência igual, tanto in vitro como in situ, o que não acontece, particularmente no interior da célula.

De Zoeten (9) afirma ter encontrado partículas curtas e longas no interior de células de fumo, infetado por um isolado do VRF da California, e considerou o fato como evidência favorável à hipótese de que as partículas curtas seriam um produto colateral, da infecção por êste vírus, mas sem atividade. Todavia aquêle autor menciona grupos de partículas em arranjos ordenados, cristalinos, que aparecem logo no início da infecção sistêmica, os quais se desagregam com o decorrer da infecção. Embora De Zoeten não mencione claramente, parece provável que as partículas curtas apareceriam após esta desagregação dos arranjos cristalinos das partículas.

Lister (25) atribui uma função às partículas curtas do VRF, baseado no fato de que, quando no inóculo não há partículas curtas, dá-se o aparecimento de isolados, ditos instáveis (6), em maior freqüência, nas subculturas das lesões formadas. Como nestes isolados instáveis admite-se que o VRF ocorra na forma de ácido ribonucléico (ARN) livre (33), Lister sugere que as partículas curtas têm em seu ARN informações que comandam o capeamento do ARN, tanto das partículas curtas como das 
longas, pela proteína. Num trabalho recente, Frost et al. (12) reinvestigaram as observações de Lister, e sugerem que cada isolado do VRF seria um sistema de dois ou mais pedaços de ARN infetivo interagindo especificamente num processo simbiótico. Se realmente a interpretação dêstes autores estiver correta, uma das maneiras de conciliá-la com as observações relatadas no presente trabalho, i.e., ausência de inclusões de partículas curtas ( $55 \mathrm{~m} \mu$ ) nos tecidos infetados, seria a admissão de que as partículas curtas poderiam formar agregados em que quatro unidades se unem pelas extremidades, e estas por sua vez formariam inclusões indistinguíveis dos grupos de partículas longas.

\section{MORPHOLOGY OF PEPPER RINGSPOT VIRUS (BRAZILIAN TOBACCO RATTLE VIRUS) PARTICLES}

\section{SUMMARY}

Tubular particles, about $25 \mathrm{~m}_{\mu}$ wide, with an axial channel $4 \mathrm{~m}_{\mu}$ in diameter, were found in leaf dip or purified preparations and also within tissues, from plants infected with pepper ringspot virus (PRSV), but not in uninoculated control plants. The particle length determinations showed two prevalent types of particles in vitro, respectively with ca. $55 \mathrm{~m}_{\mu}$ and $200 \mathrm{~m}_{\mu}$ in normal length. These values were independent of the virus isolate, host plant or preparative procedures for electron microscopy employed. In thin section profiles, a dense rim was observed bordering the axial channel, in cross section of particles stained with uranyl acetate, which might represent the location of the viral nucleic acid in the virion. The long, $200 \mathrm{~m}_{\mu}$, particles can be separated from the short, $55 m_{\mu}$ particles through sucrose gradient density ultracentrifugation, when it can be demonstrated that only the longer particles are infective.

Incubation of purified preparations with ribonuclease and/or trypsin, did not affect infectivity or the structure of the virions. However, in some experiments, the trypsin treatment induced an end-to-end aggregation of the particles.

Purified preparations lose infectivity after being heated for 10 minutes at $65-700 \mathrm{C}$. Simultaneously a generalized degradation of virions is noticeable. The end product of this degradation is a powdery material, composed of granules 30-40 $\mathrm{A}^{\circ}$ in diameter.

In ultrathin sections of PRSV-infected tissues, ordered aggregates of particles, similar to those found in vitro, were observed in the cyto- 
plasm. Such inclusions consisted of long $(200 \mathrm{~m} \mu)$ particles only. In no instance, groups of typical $55 \mathrm{~m}_{\mu}$, short particles were found, and this suggests that they are fragments of the longer, $200 \mathrm{~m}_{\mu}$ particles, rather than products of self multiplication.

\section{LITERATURA CITADA}

1. BRANDES, J. Eine elektronenmikroskopische Schnellmethode zum Nachweis fäden- und stäbchenförmiger Viren, insbesonders in Kartoffeldunkelkeimen. NachrBl. dtsch. PflSchDienst (Braunschweig) 9:151-152, 1957.

2. _ _ \& WETTER, C. Classification of elongated plant viruses on the basis of particle morphology. Virology 8:99-115, 1959.

3. __ ; PHILLIPE, M. R. \& THORNBERRYY, H. H. Electron microscopy of particles associated with soil-borne wheat mosaic. Phytopath. Z. 50:181-190, 1964.

4. BRENNER, S. \& HORNE, R. W. A negative staining method for high resolution electron microscopy of viruses. Biochim. Biophys. Acta 34:103-110, 1959.

5. CADMAN, C. H. Evidence for association of tobacco rattle virus nucleic acid with a cell component. Nature 193:49-52, 1962.

6. — \& HARRISON, B. D. Studies on the properties of soil-borne viruses of the tobacco rattle type occurring in Scotland. Ann. Appl. Biol. 47:542-556, 1959.

7. COMMONER, B. Linear biosynthesis of tobacco mosaic virus: development and test of a model. Proc. Natl. Acad. Sci., U.S. 48:2076-2085, 1962.

8. Costa, A. S.; KITAJima, E. W. \& Oliveira, A. R. Vírus do anel do pimentão: um integrante do grupo do vírus do "rattle" do fumo. (Lados não publicados)

9. DE ZOETEN, G. A. California tobacco rattle virus, its intracellular appearance and the cytology of the infected cells. Phytopathology 56:744-754, 1966.

10. FINCH, T. Resolution of the substructure of tobacco mosaic virus in the electron microscope. J. Mol. Biol. 8:872-874, 1964.

11. Preliminary X-ray diffraction studies of tobacco rattle and barley stripe mosaic viruses. J. Mol. Biol. 12:612-619, 1965.

12. FROST, R. R.; HARRISON, B. D. \& WOODS, R. D. Apparent symbiotic interaction between particles of tobacco rattle virus. J. Gen. Virol. 1:57-70, 1967.

13. HARRISON, B. D. \& NIXON, H. L. Separation and properties of particles of tobacco rattle virus with different length. J. Gen. Microbiol. 21:569-581, 1959. 
E. W. KITAJIMA \& OUTROS

14. HARRISON, B. D. \& WOODS, R. D. Serotypes and particle dimensions of tobacco rattle virus from Europe to America. Virology 28:610-620, 1966.

15. HART, R. G. Morphological changes accompanying thermal denaturation of tobacco mosaic virus. Biochim. Biophys. Acta. 30:388-389, 1956.

16. HOLMES, K. C. \& FRANKLIN, R. The radial distribution in some strains of tobacco mosaic virus. Virology $6: 328-336,1958$.

17. HORNE, R. W. \& WILDY, P. Virus structure revealed by negative staining. Adv. Virus Res. 10:101-170, 1963.

18. - RUSSEL, G. E. \& TRIM, A. R. High resolution electron microscopy of beet yellows virus filaments. J. Mol. Biol. 1:234-236, 1959.

19. HUXLEY, H. E. \& ZUBAY, G. Preferential staining of nucleic acid containing structures for electron microscopy. J. Biophys. Biochem. Cytol. 11:273-296, 1961.

20. KARNOVSKI, M. J. Simple methods for staining with lead at high $\mathrm{pH}$ in electron microscopy. J. Biophys. Biochem. Cytol. 11:729-732, 1961.

21. KITAJIMA, E. W. A rapid method to detect particles of some spherical plant viruses in fresh preparations. J. Electronmicroscopy (Tokyo) 14:119-121, 1965.

22. - SIlva, D. M.; OliveirA, A. R.; MÜLleR, G. W. \& COSTA, A. S. Electron microscope investigations on tristeza. In: Proc. 3rd. Conf. Int. Org. Citrus Virologists, $1965 . \quad$ p.1-9.

23. KLIMENTKO, S. M.; UVAROV, V. N. \& GUAJDAMOVICH, S. J. Spatial arrangement of ribonucleoprotein strand of vesicular stomatitis virus. In: Proc. 6th Int. Conf. Electron Microscopy (Kyoto), 1966. v.2. p.183-184.

24. KöHLER, E. Versuch einer Deutung der Partikellängen pflanzlicher Virusarten. Naturwissenschaften 43:230-231, 1956.

25. LISTER, R. M. Possible relationship of virus-specific products of tobacco rattle virus infection. Virology 28:350-353, 1966.

26. LUFT, J. H. Improvements in epoxy resin embedding methods. J. Biophys. Biochem. Cytol. 9:409-414, 1961.

27. MATTERN, C. F. T. Electron microscopic observations of tobacco mosaic virus structure. Virology 17:76-83, 1962.

28. MILLONIG, G. Studio sui fattori che determinano la preservazione della ultrastruttura. In: From molecule to cell-Symposium on electron microscopy. Buffa, P., ed. Roma, C.N.R., 1964. p. 347-362.

29. NIXON, H. L. \& HARRISON, B. D. Electron microscopic evidence on the structure of the pariicles of tobacco rattle virus. J. Gen. Microbiol. 21:582-590, 1959 . 
30. OFFORD, R. E. Electron microscopic investigations on the structure of the particles of tobacco rattle virus. J. Mol. Biol. 17:370-375, 1966.

31. OLIVEIRA, A. R. Serologia aplicada ao estudo do vírus do anel do pimentão. (Tese para doutoramento, E.S.A. "Luiz de Queiroz", Piracicaba, 1967) 40fls.

32. REYNOLDS, E. S. The use of lead citrate at high $\mathrm{pH}$ as an electron opaque stain in electron microscopy. J. Cell Biol. 17:208-211, 1963.

33. SÄNGER, H. L. \& BRANDENBURG, E. Über die Gewinnung von infektiösen Pressaft aus "Wintertype" Pflanzen des Tabak-Rattle-Virus durch Phenol Extraktionen. Naturwissenschften $48: 391,1961$.

34. SILVA, D. M. Estudos sôbre purificação, composição e algumas propriedades do vírus do anel do pimentão. (Tese para livre docência, E.S.A. "Luiz de Queiroz", Piracicaba, 1965) 106fls.

35. SIMPSON, R. W. \& HAUSER, R. W. Structural components of vesicular stomatitis virus. Virology 29:654-667, 1966.

36. TAKAHASHI, W.N. The effect of the high pH on the linear aggregation of the tobacco mosaic virus. Am. J. Bot. 36:642-645, 1949.

37. WATSON, M. L. Straining of tissue sections for electron microscopy with heavy metals, J. Biophys. Biochem. Cytol. 4:475-478, 1958. 